\title{
Competitive intelligence in South Africa: status quo in 2005
}

\author{
Marié-Luce Muller \\ Director, IBIS \\ mlm@ibis.co.za \\ www.ibis.co.za
}

\section{Introduction}

In the first article published on competitive intelligence (CI) in South Africa (Muller 1999), it was stated that globalization had brought about a need for better information and, more importantly, a need for the ability to translate information into knowledge and to link that knowledge to decision-making and strategy. Several factors led to the rise of CI as a tool to enhance strategic and, to a lesser extent, tactical decision making, including the quest for global competitiveness.

It is perhaps apt to revisit the state of CI in 2005 and assess how it is used, to what extent and in particular, whether CI has led to South Africa becoming more competitive as a country. Is there indeed still a case for CI and can it be said that a certain level of maturity has been reached? Or should one speak of pockets of competitive excellence rather than viewing competitiveness in more general terms?

Much has been written over the past few years on CI in South Africa, how companies conduct CI and how the discipline has developed over the past 20 years. In this article the author reviews competitiveness in a broad sense and explores competitiveness issues and challenges in South Africa.

\section{Africa, South Africa and competitiveness}

Is South Africa competitive? This is the question asked in an article published by the Icon Group (Marketresearch.com 2002). With the globalization of markets, the increased mobility of corporate assets and the need for productive human resources, this question has become all the more complex to answer. The people factor in competitiveness is often ignored when assessing the competitiveness of South Africa and this is where CI could come into play. Even with the best systems and business intelligence tools, CI will be a wasted effort if the people factor is ignored. In many instances, people's cooperation, participation and unique insights and knowledge make the difference between competitiveness and the lack thereof.

Overall, South Africa seems unable to improve its position in the global competitiveness rankings in the World Economic Forum's (WEF's) Global Competitiveness Report 2005 (WEF 2005), dropping a position from the previous year and unable to improve beyond its position over the past number of years. Tunisia, in 40th position, is the only African country to rank higher than South Africa. While South Africa's macroeconomic policies were praised in the latest report, it fell one place in the overall rankings mainly because of the business 
community's concern about crime and the country's tardiness in adopting new information technologies (Business Day 2005). According to the WEF, South Africa also needs to strengthen its effort 'to raise the levels of training and skills of the labour force'.

From a competitiveness viewpoint, South Africa, being part of Africa, also poses a number of challenges. The development and competitiveness challenges facing South Africa are similar to the ones most other African countries are facing. Although the World Bank President, Paul Wolfowitz, on a visit to South Africa said there is a real 'can do' attitude in Africa, some real competitiveness challenges are facing South Africa (World Bank 2005). These include HIV/Aids, the impact of negative perceptions (corruption, skills shortages), poverty, distance from markets and skewed economic development.

In the executive summary to the Global competitiveness report (WEF 2004), Ernesto Hernández-Catá of the Paul Nitze School of Advanced International Studies at the Johns Hopkins University wrote that there are a number of reasons for Africa's dismal performance which include expensive investment goods, low levels of education, poor health, adverse geography, relatively closed economies, too much public expenditure, HIV/Aids and devastating armed conflicts. Other challenges include corruption, the absence of rule of law, undisciplined fiscal policies, poor infrastructure and low investment. Furthermore, except for South Africa, few African countries are significantly involved in international trade. Trade participation has been hindered by insufficient education and skills, by the high 'transaction costs' of transportation and communications and sometimes by over-valued exchange rates. All these factors have played a role in eroding the competitive position of African exporters and producers.

In the lead article to this Africa Competitiveness Report, 'The economic tragedy of the twentieth century: growth in Africa', Elsa Artadi and Xavier Sala-i-Martincharacterize Africa's dismal growth performance after decolonization as 'the worst economic tragedy of the 20th century', with most sub-Saharan countries in a state of greater poverty now than they were when they became independent. The authors provide quantitative evidence to back their statements. Per capita GDP in sub-Saharan Africa is now US\$200 lower than in 1974, a decline of $11 \%$ over a quarter of a century. During this same period the rest of the world was growing at an average annual rate of $2 \%$.

One of the central components of the Global competitiveness report is theGrowth Competitiveness Index (GCI). It is designed to measure the condition of an economy and its propensity to achieve sustained economic growth in the medium to long term. It comprises the public institutions index, the technology index and the macroeconomic environment index. Botswana's top position in the GCI (see Table 1) stems from the country achieving the highest scores in terms of the state of its public institutions and the condition of its macroeconomic environment. Tunisia also scores relatively well in terms of its quality of public institutions and its macroeconomic environment. In terms of technology, however, the rankings show some room for improvement. South Africa's excellent position of first place in the technology index is a reflection of its advanced position in terms of technological progress and its capacity to innovate and compete in the global market.

\begin{tabular}{|l|l|l|l|}
\hline \multicolumn{4}{|l|}{ Table 1 Growth competitiveness index (GCI) } \\
\hline Rank & & Rank & Score \\
\hline 1 & Botswana & 36 & 4.54 \\
\hline 2 & Tunisia & 38 & 4.49 \\
\hline 3 & South Africa & 42 & 4.37 \\
\hline 4 & Mauritius & 46 & 4.12 \\
\hline 5 & Namibia & 52 & 3.99 \\
\hline & & &
\end{tabular}




\begin{tabular}{|l|l|l|l|}
6 & Gambia & 55 & 3.93 \\
\hline 7 & Egypt & 58 & 3.84 \\
\hline 8 & Morocco & 61 & 3.77 \\
\hline 9 & Tanzania & 63 & 3.49 \\
\hline 10 & Ghana & 71 & 3.46 \\
\hline 11 & Algeria & 74 & 3.39 \\
\hline 12 & Malawi & 76 & 3.36 \\
\hline 13 & Senegal & 79 & 3.34 \\
\hline 14 & Uganda & 80 & 3.25 \\
\hline 15 & Kenya & 83 & 3.21 \\
\hline 16 & Nigeria & 87 & 3.10 \\
\hline 17 & Zambia & 88 & 3.10 \\
\hline 18 & Cameroon & 91 & 2.98 \\
\hline 19 & Ethiopia & 92 & 2.92 \\
\hline 20 & Mozambique & 93 & 2.91 \\
\hline 21 & Madagascar & 96 & 2.85 \\
\hline 22 & Zimbabwe & 97 & 2.84 \\
\hline 23 & Mali & 99 & 2.79 \\
\hline 24 & Angola & 108 & 2.60 \\
\hline 25 & Chad & 101 & 2.31 \\
\hline Source: Africa Competitiveness Report 2004 \\
\hline
\end{tabular}

\section{Early days of CI}

CI really took root in South Africa in the mid 1990s and early 2000s. While there are a myriad companies only now starting to take better cognizance of their external competitive environment, it is also true that many companies and institutions in all industries have developed sophisticated CI capabilities and are moving beyond the implementation and refining phases into recognizing $\mathrm{CI}$ for its true purpose, that is, as a constant radar on the lookout for opportunities and threats, a tool to enhance company knowledge and promote innovation and a constant input in strategic decision making.

Level of CI in SA companies: 2004

The current level of CI can at best be described as higher than about five years ago but with pockets of excellence rather than generally more sophisticated and formal CI. In a study into the CI practices of South African companies (Viviers, Saayman and Muller 2004), it was found that large South African companies, especially those active in the manufacturing sector, showed an improvement in the level of CI applied since 1999. While the 1999 survey (Muller 1999) indicated negligible levels of CI being conducted in South Africa, the Viviers survey showed that CI is more common in South African companies than it was in 1999. However, the results indicate that CI is still mostly practiced part-time in South Africa and that it resides mostly within the marketing department (in other words it is not companywide at a strategic level). Encouragingly, CI develops with the focus on the right sources of information, namely people, on the right targets (not only on competitors), and on the right actions (not just collecting, but also interpreting information). In most cases key executives, such as the chief operating officer or the chief executive officer accept the final responsibility for CI, indicating the growing importance of this discipline within South African companies.

Concerning the level of CI implementation, the study concludes that South African companies are not as developed yet in CI as their North American and European counterparts. The study did however indicate some positive factors including acknowledgement by senior management that CI can be used to create a competitive 
advantage and that it is a legitimate and necessary activity for increasing their intelligence and knowledge of their competitive environment.

In general, results show that South African companies are not yet as well equipped to conduct good CI practices as their counterparts in the United States, Japan, Sweden, France, Israel and others (Kahaner 1996).

There is a general acknowledgment among South African business persons that in order to survive, let alone prosper, in a changed competitive environment, they will have to take a new view of that environment. The value of knowledge building and pooling to secure a competitive edge over competitors that have access to very much the same information is recognized. It follows that by conducting CI effectively, these factors can be addressed and could put companies on the road of recovery and higher profits.

Experience from a consulting viewpoint has shown that instead of embarking on a road of implementing comprehensive CI systems in companies, companies are rather opting for outsourcing many aspects of CI (most notably gathering data and information and tracking and scanning of the competitive environment) and are conducting CI on a part-time, ad hoc manner. It goes without saying that the need for CI remains vast. That CI will grow and become more institutionalized is beyond doubt.

Prescott (1999) provides a description of how the leading-edge companies of the future will use CI:

'The CI process within a multinational company is institutionalized on a worldwide basis although there is local responsiveness. The vast majorities of the employees appreciate the value of CI and participate in the process including counter-intelligence efforts. Data analysis is extensive with qualitative input often dominating quantitative data. The intelligence is integrated directly into strategic decisions often through sophisticated information systems. Top management uses CI as one of the ways it shapes the future of the organization and considers it an integral part of the learning organization. A key component of the companies of the future is that managing behavioural dimensions of CI becomes critical. While collection and analysis are important, how organizations mobilize the informal CI process will determine their effectiveness.'

\section{Conclusion}

South Africa and its companies and industries continue to face a number of competitiveness challenges and $\mathrm{CI}$ is one activity that could improve competitiveness.

While awareness of the importance of CI is wide, it is still not practiced optimally. From a country perspective, the need for creating awareness of the benefits of $\mathrm{CI}$ is equally important. Awareness creation has been done with success in other countries through the cooperation between media advocacy, workshops, training organizations, academic courses as well as full support and participation of CI activities by the government. To enhance South Africa's competitiveness through the more effective use of CI, this cooperation model is highly recommended. This might prove to be one of the building blocks to improving Africa's overall competitiveness.

\section{References}

1. Global competitiveness report. 2004. Executive summary. World Economic Forum.

2. Kahaner, L. 1996. Competitive intelligence: from black ops to boardrooms. How businesses gather, analyze, and use information to succeed in the global marketplace. New York: Simon and Schuster. 
3. Market Research.com. 2002. The economic competitiveness of South Africa: financials returns, labor productivity and international gaps. Icon Group International. [Online]. www.marketresearch.com/map/prod/804670.html (Accessed October 2005)

4. Muller, M-L. 1999. South Africa: An emerging CI Player. Competitive Intelligence Review 10(4):74-78.

5. Prescott, J. E. 1999. The evolution of competitive intelligence. Proposal Management (Spring):37-52.

6. Viviers, W., Saayman, A. and Muller, M-L. 2004. Competitive intelligence: 19992002 and beyond. Africa Insight 34(2):90-96.

7. World Bank. 2005. [Online].

8. www.web.worldbank.org/WBSITE/EXTERNAL/NEWS/0,,contentMDK:20549881 $\sim$ menuPK:34469 pagePK:34370 piPK:34424 theSitePK:4607,00.html (Accessed October 2005).

\section{About the author:}

Marié-Luce Muller is a consulting CI analyst with IBIS Business and Information Services (Pty) Ltd, a leading Pretoria-based CI consultancy. She has a distinguished career in CI. Her primary experience lies in assisting companies in honing their CI capabilities. She also performs tracking and scanning activities on behalf of companies. Marié-Luce has published many articles on competitive intelligence (CEO Magazine, Finance Week, Business Week, Beeld, Die Burger and the South African Journal of Business Management), including an article on South Africa as an emerging CI player, which was published in an international publication of the Society of Competitive Intelligence Professionals (SCIP). She has also published a series of booklets on CI (Nuts and Bolts business series, published by Knowledge Resources) and is a member of a research team participating in an international study of CI practices among exporting companies. Previously, she was involved in research into the status of CI practices in South Africa. A member of SCIP, she holds a postgraduate degree from the University of Stellenbosch.

\section{Disclaimer}

Articles published in SAJIM are the opinions of the authors and do not necessarily reflect the opinion of the Editor, Board, Publisher, Webmaster or the Rand Afrikaans University. The user hereby waives any claim he/she/they may have or acquire against the publisher, its suppliers, licensees and sub licensees and indemnifies all said persons from any claims, lawsuits, proceedings, costs, special, incidental, consequential or indirect damages, including damages for loss of profits, loss of business or downtime arising out of or relating to the user's use of the Website.

ISSN 1560-683X

Published by InterWord Communications for Department of Information and Knowledge Management, University of Johannesburg 